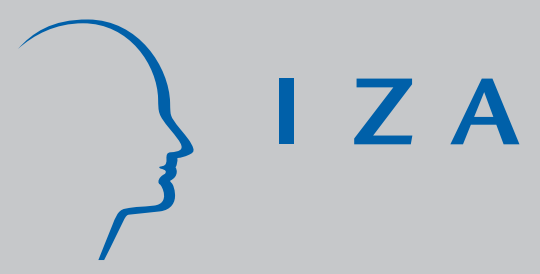

IZADP No. 2874

Entrepreneurship, Wealth, Liquidity Constraints and Start-up Costs

Raquel Fonseca

Pierre-Carl Michaud

Thepthida Sopraseuth

J une 2007 


\title{
Entrepreneurship, Wealth, Liquidity Constraints and Start-up Costs
}

\author{
Raquel Fonseca \\ RAND \\ Pierre-Carl Michaud \\ RAND and IZA \\ Thepthida Sopraseuth \\ EPEE, University of Evry
}

Discussion Paper No. 2874

June 2007

IZA

P.O. Box 7240

53072 Bonn

Germany

Phone: +49-228-3894-0

Fax: +49-228-3894-180

E-mail: iza@iza.org

\begin{abstract}
Any opinions expressed here are those of the author(s) and not those of the institute. Research disseminated by IZA may include views on policy, but the institute itself takes no institutional policy positions.

The Institute for the Study of Labor (IZA) in Bonn is a local and virtual international research center and a place of communication between science, politics and business. IZA is an independent nonprofit company supported by Deutsche Post World Net. The center is associated with the University of Bonn and offers a stimulating research environment through its research networks, research support, and visitors and doctoral programs. IZA engages in (i) original and internationally competitive research in all fields of labor economics, (ii) development of policy concepts, and (iii) dissemination of research results and concepts to the interested public.
\end{abstract}

IZA Discussion Papers often represent preliminary work and are circulated to encourage discussion. Citation of such a paper should account for its provisional character. A revised version may be available directly from the author. 


\section{ABSTRACT \\ Entrepreneurship, Wealth, Liquidity Constraints and Start-up Costs}

We study the effects of liquidity constraints and start-up costs on the relationship between wealth and the fraction of entrepreneurs in an economy. We develop a dynamic occupational choice model with endogenous wealth and entry into entrepreneurship. The model predicts that, with liquidity constraints, the probability of entering entrepreneurship is an increasing function of individual wealth while the introduction of start-up costs tends to flatten this relationship. The theoretical predictions can be tested on cross-sectional data with exogenous variation in liquidity constraints (e.g. access to credit) and business start-up costs. We use three highly comparable micro datasets (SHARE, ELSA and HRS) providing harmonized data on wealth and work status in 9 countries that characterized by very different levels of start-up costs and liquidity constraints. Our results support our theoretical predictions. While higher liquidity constraints yield a positive relationship with wealth profile for the fraction of workers in entrepreneurship, start-up costs weaken this relationship by depressing the marginal value of being an entrepreneur as a function of wealth. Countries with high start-up costs such as Italy, Spain and France have flatter wealth gradients.

JEL Classification: E20, D31, J62

Keywords: entrepreneurship, wealth, liquidity constraints, start-up costs

Corresponding author:

Pierre-Carl Michaud

RAND Corporation

1776 Main Street

P.O. Box 2138

Santa Monica, CA 90407-2138

USA

E-mail: michaud@rand.org

\footnotetext{
* We thank Thierry Debrand and Magnus Henrekson for helpful comments as well as audiences in RTN Aging (Paris, 2006), SHARE - ELSA - HRS Conference (Los Angeles, 2006), T2M Conference (Paris, 2007), Conference on Entrepreneurship (Chicago, 2007), Society of Labor Economics (Chicago, 2007).
} 


\section{Introduction}

Over the last two decades, self-employment and entrepreneurship have attracted attention in public policy circles as well as in labor economics. Self-employment is seen by many as a form of employment that may help resolve aging-related fiscal problems since such workers tend to retire later. It is also seen as an engine of entrepreneurial activity that has the potential to deliver more jobs in the future. It then seems crucial to identify what drives entrepreneurship.

Self-employment is not a marginal phenomenon in most OECD countries (Blanchflower, 2000). In a recent study, Hochguertel (2005) finds that very little of the difference in self-employment rates across European countries is explained by observable characteristics of workers. This leaves considerable room for institutions to play a role. Using a theoretical model, Fonseca et al. (2001) show fewer individuals become entrepreneurs when start-up costs are higher. On the other hand, Evans and Jovanovic (1989) find that, in a credit constrained environment, the probability of entrepreneurship increases with assets. Evans and Leighton's (1989) findings on US data support this hypothesis. The importance of liquidity constraints and access to capital is supported by empirical evidence presented by Blanchflower and Oswald (1998) and Guiso, Sapienza and Zingales (2002).

This paper investigates how the interactions between start-up costs and individual asset holdings can affect the fraction of entrepreneurship in an economy. The literature has focused so far on liquidity constraints and wealth: entrepreneurs have to obtain bank loans in order to set up their own business. Since wealth plays the role of collateral in a bank loan, the probability of becoming entrepreneur increases with individual wealth. Hurst and Lusardi (2004) have disputed the relevance of borrowing constraints to entrepreneurial entry. They find that the positive wealth-business entry relationship is unlikely to reflect the existence of liquidity constraints. Their key argument is that the probability of entrepreneurship in the US increases only for extremely rich individuals who are less likely to be liquidity constrained. We take a new look at this relationship with the introduction of start-up costs.

We build on dynamic occupational choice models along the lines of Cagetti and De Nardi (2005), Luo (2005) and Quadrini (2000). ${ }^{5}$ Quadrini (2000) aims at replicating the aggregate wealth inequality, driven in particular by the concentration at the top of the the wealth distribution. He argues that the entrepreneurs' high savings rate can explain the wealth concentration among the richest individuals. Cagetti and DeNardi (2005) also replicate the wealth dispersion using a model of entrepreneurship and identify the specific effect of borrowing constraints on entrepreneurship entry. Luo (2005) develops a model of occupational choice to explore the implications of uninsurable entrepreneurial risk on wealth distribution.

Our paper focuses on the effect of liquidity constraints and start-up costs on the relationship between wealth and the fraction of entrepreneurs in an economy. We consider a model of heterogeneous agents with occupational choice. Wealth and entry into entrepreneurship are endogenous. Entrepreneurs can borrow capital from banks to set up or expand their business. However, because of limited enforceability of loan contracts, banks are

\footnotetext{
${ }^{5}$ There is an abundant literature on models analyzing the decision to become entrepreneur and wealth choices in an economy with imperfect financial markets, i.e. Evans and Jovanovic (1989), Holtz-Eakin et al. (1994), Blanchflower and Oswald (1998) Gentry and Hubbard (2000) among others.
} 
reluctant to grant credit to entrepreneurs with low levels of wealth. Wealth plays the role of collateral and limits default. We introduce additional institutional features, namely start up costs, to the model. In addition to savings and entrepreneurial choices, following Cagetti and DiNardi (2005), we allow the individual to consider inactivity. Indeed, old individuals may withdraw from the labor force rather than continuing activity. We then get a complete picture of occupational choices in old age as a less generous old age pension may entice individuals to delay retirement and consider starting their own business. They can also have strong incentives to be inactive (retirement, unemployment or disability can be here interpreted as being inactive). Start up costs, by shifting the expected entrepreneurial gains, may actually affect these choices. The model predicts that with liquidity constraints, the probability of entering entrepreneurship is an increasing function of individual wealth. The originality of our paper is to show that the introduction of start-up costs tends to flatten this relationship. This is highly relevant since we show that start-up costs and liquidity constraints are positively correlated across countries but have different effect on the relationship of entrepreneurship with wealth.

In order to test the predictions of the model, we use three comparable micro datasets (HRS, SHARE and ELSA) that provide harmonized measures of individual wealth and work status. These data focus on the population aged $50+$ in 9 countries. The model yields predictions on the stationary distribution of wealth that can be tested using cross-sectional data where variation in liquidity constraints (access to capital) and start-up costs is available. These countries have very different levels of start-up costs and liquidity constraints measured by the facility with which entrepreneurs have access to capital. We use various indices from the literature to characterize the institutional setup in each country (La Porta et al., 1998; Nicoletti et al., 1999; Fonseca et al., 2001; Acs et al., 2004).

Empirical results support our theoretical predictions. While liquidity constraints yield a steeper wealth gradient for the fraction of workers in entrepreneurship, start-up costs flatten this relationship by depressing the marginal value of being an entrepreneur as a function of initial wealth. Countries with high start-up costs such as Italy, Spain and France have flatter wealth gradients for the fraction of entrepreneurs in this age group. In other words, the interaction between business start up costs and liquidity constraints affects the decision to become an entrepreneur.

In Section 2 and 3, we present the data used to test predictions. In section 4, we set up the model, and generate predictions on the effect of liquidity constraints and start-up costs on the relationship between wealth and the fraction of entrepreneurs in an economy. In section 5, we test the empirical relevance of the model's predictions using a multinomial choice model. Section 6 concludes.

\section{Entrepreneurs in Europe and US}

We use three comparable datasets composed of individuals aged 50+ in 9 countries. The Survey of Health, Ageing and Retirement in Europe (SHARE) was fielded in 2004 and composed of representative samples of the population in 10 European countries. For this analysis, we keep Germany, Sweden, The Netherlands, Spain, Italy, France and Denmark. Because of small sample size, we decided not to use data from Switzerland. In addition, because we could not find good comparable measures of the regulatory environment in Austria and Greece we did not include those countries either in our analysis. Two additional 
countries can be included because of the availability of comparable datasets; the United States using the Health and Retirement Study (HRS) and England using the English Longitudinal Study of Ageing (ELSA). We use the 2002 wave from the HRS and the 2003 wave from ELSA. We only keep respondents between 50 and 80 years old, 50 is the minimum age to be eligible to the survey and 80 is the maximum age because there are very few people into the labor market after this age. An analysis over the whole life-cycle would have been preferable but no wealth data as rich as the ones used here are available to perform such analysis. Hence, we concentrate on this segment of the population. Definitions of variables are displayed in Appendix A.

We use self-employment as our definition of entrepreneurship. ${ }^{6}$ Although this definition has drawbacks, it avoids having to deal with the joint ownership of business assets and other complicated arrangements. We refer to these self-employed workers as entrepreneurs. In Table 1, we show the fraction of respondents not working, working for pay, and entrepreneurs. We can point out that the percentage of entrepreneurs varies considerably across countries. For example, among the population aged 50-80, there are only $5.2 \%$ entrepreneurs in France while there are $11.76 \%$ entrepreneurs in Italy, $10.89 \%$ in Spain and $10.4 \%$ in United States. The fraction in inactivity also varies remarkably. In Italy and in Spain, almost two thirds of the non working population is inactive at this age while less than a half is inactive in United States, in Sweden and in Denmark. This is highly correlated with the generosity of pension systems across countries as can be seen from the last column of Table 1. Hence, as a fraction of the labor force, the variation in entrepreneurship is inflated by differences in exit (or retirement) rates. ${ }^{7}$

Table 1 Occupational Status by Country Population Aged 50-80

\begin{tabular}{lrrrr} 
Country & Non Working & Workers & Entrepreneur Net Retirement RR \\
\hline \hline United States & 46.7 & 42.94 & 10.36 & 51 \\
England & 50.05 & 40.06 & 9.89 & 48 \\
Germany & 59.37 & 33.66 & 6.97 & 72 \\
Sweden & 41.35 & 50.08 & 8.57 & 68 \\
The Netherlands & 57.19 & 36.5 & 6.31 & 84 \\
Spain & 63.24 & 25.88 & 10.89 & 88 \\
Italy & 68.54 & 19.7 & 11.76 & 89 \\
France & 59.67 & 35.09 & 5.24 & 69 \\
Denmark & 45.74 & 47.66 & 6.6 & 54 \\
\hline \hline
\end{tabular}

Source: HRS, ELSA and SHARE, population below 80 and older than 50 years old, weighted. Net Retirement Remplacement Ratios reported by Blondal and Scarpetta (1999).

Other studies have pointed out individual patterns among self employed (Blanchflower (2000), Hochguertel (2005) and Zissimopoulos and Karoly (2007)). We find similar patterns for the main variables. The probability of being entrepreneur is higher with characteristics such as being men, married, with education, in good health and being in large household size. These patterns are similar in all countries. Table 2 displays descriptive statistics for the different groups (non working, workers and entrepreneurs).

\footnotetext{
${ }^{6}$ All self-employed work for pay. Unpaid self employed are included in the inactivity group.

${ }^{7}$ As a fraction of workers, these differences are exacerbated in Italy and Spain since the fraction in paid employment is rather low, i.e. the share of entrepreneurs as a fraction of workers (own computations of HRSELSA-SHARE datasets) for Spain (26.75) and Italy (35.28) versus US (19.43\%) and England (17.89\%).
} 
Table 2 Individual Characteristics

\begin{tabular}{llrr} 
& & Mean & Standard Deviations \\
\hline \hline Non working & male & $42 \%$ & $49 \%$ \\
& married & $71 \%$ & $45 \%$ \\
& household size & 2.21 & 1.01 \\
& high educated & $19 \%$ & $39 \%$ \\
& health good & $39 \%$ & $49 \%$ \\
workers & health fair/poor & $37 \%$ & $48 \%$ \\
& male & $52 \%$ & $50 \%$ \\
& married & $72 \%$ & $45 \%$ \\
entrepreneur & household size & 2.38 & 1.12 \\
& high educated & $40 \%$ & $49 \%$ \\
& health good & $38 \%$ & $49 \%$ \\
& hale & $14 \%$ & $35 \%$ \\
& married & $65 \%$ & $48 \%$ \\
& household size & $75 \%$ & $43 \%$ \\
& high educated & 2.46 & 1.15 \\
& health good & $38 \%$ & $49 \%$ \\
& health fair/poor & $41 \%$ & $49 \%$ \\
Total & male & $43 \%$ & $34 \%$ \\
& married & $72 \%$ & $50 \%$ \\
& household size & 2.29 & $45 \%$ \\
& high educated & $28 \%$ & 1.07 \\
& health good & $39 \%$ & $45 \%$ \\
& health fair/poor & $27 \%$ & $49 \%$ \\
& & & $44 \%$ \\
\hline \hline
\end{tabular}

One of the major strengths of each dataset is that they provide comparable measures of wealth. We define wealth as the sum of the net value of housing, stocks, bonds, saving accounts, private retirement accounts and other annuities minus all debt the household may have. ${ }^{8}$ This definition does not include business assets which is consistent with the definition that we will use in the model in the section 4 . We adjust wealth levels for purchasing power parity using OECD figures.

Table 3 Net Wealth by Occupational Status and Percentiles

\begin{tabular}{lcrrrrrrrr} 
Net Wealth & $\mathrm{p} 5$ & & $\mathrm{p} 10$ & $\mathrm{p} 25$ & $\mathrm{p} 50$ & $\mathrm{p} 75$ & $\mathrm{p} 90$ & $\mathrm{p} 95$ & $\mathrm{p} 99$ \\
\hline \hline & & & & & & & & & \\
non working & 0.416 & 2.948 & 35.753 & 130.221 & 264.206 & 470.413 & 670.443 & 960.772 \\
workers & 3.570 & 9.784 & 54.601 & 141.551 & 282.143 & 477.605 & 641.757 & 928.225 \\
entrepreneur & 3.824 & 20.357 & 89.917 & 219.873 & 401.111 & 632.117 & 779.951 & 971.276 \\
Total & 1.124 & 5.670 & 45.991 & 139.572 & 283.117 & 493.513 & 676.218 & 955.333 \\
\hline \hline
\end{tabular}

Source: HRS, ELSA and SHARE, population below 80 and older than 50 years old, weighted. Net Wealth by occupation status and percentiles

Net wealth by occupational status and percentiles (over all countries) is shown in table 3. From these figures, it is clear that entrepreneur have more financial wealth then other respondents, although differences seem to vanish at the top of the wealth distribution. This can reflect differences in ability or ex ante wealth (wealth prior to entry) or ex post differences in the returns to entrepreneurship. The theoretical model we present latter addresses these issues.

\footnotetext{
${ }^{8}$ See table A.2. in appendix A for more details.
} 


\section{Institutional variables}

In SHARE, only one wave of data is available although it is projected to follow respondents over time in the future. With a panel, we could study the probability of entry into entrepreneurship as a function of initial (ex ante) wealth. However, we claim that we can use international institutional variation, for example in start up costs and liquidity constraints, to show how the relationship between wealth and the probability of entrepreneurship varies across countries.

We first document whether start-up costs and financial barriers to entrepreneurship are different across countries. There is a considerably large literature devoted to the construction of various indices of start-up costs and financial barriers to entrepreneurship, these data are mainly collected from ranking and categorical scorings. Because each index measures different dimensions of the entrepreneurship environment, we aggregate them in two families using principal component analysis. ${ }^{9}$ The first index measures start-up costs. The second index captures the extent of liquidity constraints across countries. Data are displayed in table 4.

(i) Index of start-up costs is constructed from indices provided in Nicoletti et al. (1999) and Fonseca et al. (2001). The index of start-up costs is based on three components:

- regulatory and administrative opacity, defined as transparency in licenses and permits system and communication (see Nicoletti et al. 1999),

- simplification of rules and procedures administrative burdens on start-ups, defined as number of procedures to set up a business (see Nicoletti et al. 1999)

- and start ups cost index pondering procedures and week to open a establishment (see Fonseca et al. 2001). ${ }^{10}$

(ii) Index of liquidity constraints is also based on three components. Indices are constructed from GEM (2004), Global Entrepreneurship Monitor Global dataset and La Porta et al. (1998).

- government subsidies, Angel investments and Venture Capital, capturing the among of capital available to start a business, Reynolds et al.(2005).

- financial help to start-ups which includes such things as taxes and business regulations, and government support (see Acs et al. 2006) .

- $\quad$ and creditor rights, bankruptcy and reorganization laws (see La Porta et al. 1998)

\footnotetext{
${ }^{9}$ Each index is centered on zero and normalized to have unit variance.

${ }^{10}$ Start-up costs index $=$ no. of weeks + no. of procedures/average $n^{\circ}$ of procedures per $\left.*_{w e e k}\right) / 2$ Data on administrative burdens on the creation of corporate and sole proprietor businesses in Nicoletti et al. (1999) and in Fonseca et al. (2001), are taken from a study prepared for the European Commission Logotech, S.A. (1997).
} 


\section{Table 4 Construction of Indices of start-up costs and financial barriers to entrepreneurship}

\begin{tabular}{|c|c|c|c|c|}
\hline \multicolumn{5}{|c|}{ Start-up cost index } \\
\hline Country & Burdens & Opacity & $\begin{array}{c}\text { Index } \\
\text { Proc./weeks }\end{array}$ & $\begin{array}{l}\text { Start-up costs } \\
\text { index }\end{array}$ \\
\hline United States & 0.75 & 2.11 & 3.1 & -0.937 \\
\hline England & 0.78 & 0.09 & 3.9 & -0.49 \\
\hline Germany & 2.53 & 2.69 & 6.4 & 0.014 \\
\hline Sweden & 1.04 & 3.56 & 4.9 & -0.821 \\
\hline The Netherlands & 1.59 & 1.39 & 5.9 & -0.152 \\
\hline Spain & 2.79 & 1.23 & 9.9 & 0.829 \\
\hline Italy & 4.49 & 0.63 & 13.9 & 2.044 \\
\hline France & 3.93 & 2.6 & 9.4 & 0.908 \\
\hline Denmark & 0.43 & 2.51 & 2.4 & -1.204 \\
\hline \multicolumn{5}{|c|}{ Financial barriers index } \\
\hline Country & $\begin{array}{l}\text { Governmen } \\
\text { subsidies } \\
\text { /Angel I./ } \\
\text { Venture C. }\end{array}$ & Finance help & Credit Rights & Financial barriers \\
\hline United States & 11 & 11 & 1 & -1.389 \\
\hline England & 6 & 7 & 4 & -0.5 \\
\hline Germany & 8 & 8 & 3 & -0.798 \\
\hline Sweden & 1 & 4 & 2 & 1.068 \\
\hline The Netherlands & 9 & 9 & 2 & -0.939 \\
\hline Spain & 4 & 3 & 2 & 0.754 \\
\hline Italy & 2 & 1 & 2 & 1.37 \\
\hline France & 3 & 2 & 0 & 1.395 \\
\hline Denmark & 10 & 6 & 3 & -0.804 \\
\hline
\end{tabular}

Figure 1 displays the values assigned to each country along the two dimensions we look at. From Figure 1, we see that indices are positively correlated. High start-up costs are usually associated with high liquidity constraints. Southern European countries are clearly distinct from Anglo-Saxon and Germanic countries in this regard. Sweden stands out as different with relatively higher potential for liquidity constraints but low start-up costs (GEM (2004)). This shows that the set of countries we consider are heterogeneous in terms of startup costs and liquidity constraints. 
Figure 1 Indices of Start-up Costs and Liquidity Constraints

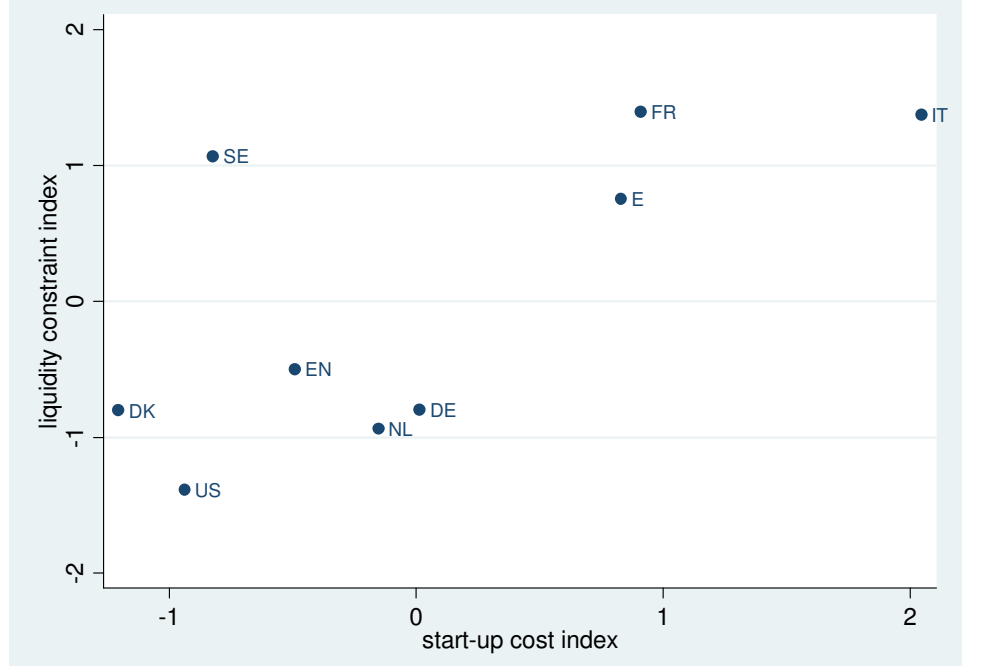

Notes: DK = Denmark, US = U.S., SE = Sweden, EN = England, NL = Netherlands, $\mathrm{DE}=$ Germany, $\mathrm{E}=$ Spain, $\mathrm{FR}=$ France, $\mathrm{IT}=$ Italy .

\section{A Simple Model of Entrepreneurship}

We build a simple model of entrepreneurship along the lines of Cagetti and De Nardi (2005), Luo (2005) and Quadrini (2000). In particular, following Cagetti and De Nardi (2005) and Luo (2005), we consider a model of heterogeneous agents with occupational choice. Wealth and entry into entrepreneurship are endogenous. Entrepreneurs can borrow capital from banks to set up or expand their business. However, because of limited enforceability of loan contracts, banks are reluctant to grant credit to entrepreneurs with low levels of wealth. Wealth plays the role of collateral and limits default. Business starts up costs are claimed in literature as a constraint in the decisions to become entrepreneurship. Fonseca et al. (2001) show how start ups cost affect to employment and to the fractions of entrepreneurs in a matching model with agents with different abilities. We add start up costs to the model and we study in what can affect entry costs when we interact with liquidity constraints.

In addition to savings and entrepreneurial choices, we allow the individual to consider inactivity. Indeed, old individuals may withdraw from the labor force rather than continuing activity. This allows to get a complete picture of occupational choices in old age as a less generous old age pension may entice individuals to delay retirement and consider starting their own business. They can also have strong incentives to be inactive (retirement, unemployment or disability can be here interpreted as being inactive). In addition, start up costs, by shifting the expected entrepreneurial gains, may actually affect these choices.

Each person possesses two abilities, entrepreneurial and worker, which we take to be exogenous, positively correlated over time, and uncorrelated with each other. 
- Entrepreneurial ability $(\theta)$ is the capacity to invest capital more or less productively,

- Working ability $(\varepsilon)$ is the capacity to produce income out of labor.

\subsection{Corporate Sector}

The non-entrepreneurial technology is represented by a standard Cobb-Douglas production function

$$
F\left(K_{c}, L_{c}\right)=A_{c} K_{c}^{\alpha} L_{c}^{1-\alpha}
$$

where $K_{c}$ and $L_{c}$ denote the total capital and labor inputs in the non-entrepreneurial sector and $A$ is a constant capturing the technology scale. In both sectors, capital depreciates at a rate $\delta \in[0,1]$. The scalar $\alpha$ represents the share of capital in production. The problem solved by the non-entrepreneur sector is

$$
\underset{L_{c}, K_{c}}{\operatorname{Max}} \Pi=A K_{c}^{\alpha} L_{c}^{1-\alpha}-w L_{c}-(r+\delta) K_{c}
$$

which has the usual first-order conditions, $w=(1-\alpha) \frac{F\left(K_{c}, L_{c}\right)}{L_{c}}$ and $r+\delta=\alpha \frac{F\left(K_{c}, L_{c}\right)}{K_{c}}$ where $w$ and $r$ are the real wage and real interest rate respectively.

\subsection{Entrepreneurs}

Entrepreneurs can borrow and invest capital in a technology whose return depends on the entrepreneurs' own entrepreneurial ability: those with higher ability levels have higher average and marginal returns from capital. When the entrepreneur invests some working capital $k$, production is

$$
A \theta k^{v}, \quad 0 \leq v \leq 1
$$

As in Evans and Jovanovic (1989), Gentry and Hubbard (2000), Cagetti and DeNardi (2005) and Luo (2005), the scalar $v$ is set smaller than one to reflect decreasing returns from investment, as entrepreneur's managerial skills become gradually stretched over larger and larger projects. Hence, while entrepreneurial ability is exogenously given, the entrepreneurial rate of return from investing in capital is endogenous and is a function of $k$ the size of the project that the entrepreneur implements. This assumption is consistent with empirical estimates of return to scale (Harada (2004)).

Following Cagetti and De Nardi (2005) and Luo (2005), we assume that entrepreneurs work on their own project without hiring labor and that all of the workers are hired by the non-entrepreneurial sector. Imperfect enforceability of contracts means that the creditors will not be able to force the debtors to fully repay their debts as promised, but that the debtors fully repay only if it is in their own interest to do so. Since both parties are aware of this feature and act rationally, the lender will lend to a given borrower an amount (possibly zero) that will be in the debtor's interest to repay as promised.

To invest $k$, the entrepreneur borrows $(k-a)$ from a financial intermediary at the real interest rate $r$, which is the risk-free interest rate at which people can borrow and lend in this economy. At the beginning of the current period, after observing the ability shocks, the 
entrepreneur determines the demand for capital to maximize his profits, given his financial asset $a$. His profit function is:

$$
\operatorname{Max}_{k} \pi(\theta, a)=A \theta k^{v}-\delta k-r \underbrace{(k-a)}_{\text {borrowing }}
$$

subject to

$$
\pi(\theta, a) \geq \underbrace{(1-\kappa) \pi(\theta, a)+(1+r)(k-a)}_{\text {entrepreneur'sincome if default }} \quad \text { with } 0 \leq \kappa \leq 1, k \geq 0 .
$$

The constraint captures the incentive compatibility constraint implying that total entrepreneur's profits need to be higher than entrepreneur's income if he defaults, i.e., we cannot observe any default in equilibrium. The first term of the right hand side of that equation is the profit that the household keeps for herself and the second term is the amount of payments to the financial intermediary that it saves because of default.

The scalar $\kappa$ denotes the fraction kept by the bank in case of default, thereby capturing the tightness of borrowing constraints or the degree of the enforceability of the loan contract. As $\kappa$ increases, the entrepreneur's income in case of default falls, thereby reducing the incentive to default: the enforceability of the loan contract improves, the bank is willing to lend more to finance entrepreneurial activities which allows entrepreneurs to expand their business. The compatibility constraint can be rewritten as

$$
\kappa \pi(\theta, a) \geq(1+r)(k-a)
$$

The compatibility constraint defines the maximum amount that can be borrowed by the entrepreneur. Entrepreneurs are endogenously divided into two groups, depending on their incentive to default.

Group 1: The constraint is $\kappa \pi(\theta, a) \leq(1+r)(k-a)$. The incentive constraint is not binding. The unconstrained household chooses the amount of invested capital $k_{\text {unconstr }}$ such that the cost of capital equals the marginal productivity of capital.

$$
A \theta v k^{v-1}=(r+\delta) \text { so that } k_{\text {unconstr }}=\left(\frac{A \theta v}{r+\delta}\right)^{\frac{1}{1-v}} .
$$

This demand for capital does not depend on initial wealth but only on technological parameters. With only one level of entrepreneurial ability and in absence of borrowing constraint, there would be only one optimal investment size. Without limited liability, as entrepreneurs can borrow any amount from the bank, occupational choice would not depend on wealth.

Group 2: The constraint is $\kappa \pi(\theta, a)=(1+r)(k-a)$, the incentive constraint is binding. The capital demand is constrained. The no default condition implies

$$
\kappa \pi(\theta, a)=(1+r)\left(k_{\text {constr }}-a\right)
$$

which defines an upper bound to the investment project $k$ implemented by the entrepreneur. The demand for capital depends on ex ante wealth $a$, indicating that the loan granted to the entrepreneur depends on the household wealth that can be pledged as collateral. In our framework, wealth plays the role of collateral and limits default: the higher is the amount of household wealth invested in the business, the larger is the sum that the bank is able to recover. ${ }^{11}$ With limited liability, the demand for capital becomes increasing in wealth for

\footnotetext{
11 Paulson, Townsend and Karaivanov (2006) consider a model of occupational choice when financial constraints stem from two sources: limited liability and moral hazard. In our framework, we will consider only the limited liability environment.
} 
constrained entrepreneurs until the entrepreneur has enough wealth to operate at the unconstrained level.

\subsection{Individual's occupation choice}

At the beginning of each period, current ability levels are known with certainty, while next period's levels are uncertain. Each individual starts the period with assets $a$, entrepreneurial ability $\theta$, working ability $\varepsilon$ and chooses whether to remain an entrepreneur or a worker or being inactive during the next period. The entrepreneur's problem is

$$
\begin{aligned}
V_{e}(a, \mathcal{E}, \theta)=\operatorname{Max}_{c, a^{\prime}}\{u(c)+ & \left.\beta E \operatorname{Max}\left(V_{e}\left(a^{\prime}, \mathcal{E}^{\prime}, \theta^{\prime}\right), V_{w}\left(a^{\prime}, \mathcal{E}^{\prime}, \theta^{\prime}\right), V_{r}\left(a^{\prime}, \mathcal{E}^{\prime}, \theta^{\prime}\right)\right)\right\} \\
a^{\prime} & =\pi(\theta, a)+(1+r) a-c \\
a & \geq 0
\end{aligned}
$$

where $V_{e}, V_{w}$ and $V_{r}$ denote the expected utility associated with being an entrepreneur, a worker and a retiree (inactive) respectively. The expectation term in value functions capture the idiosyncratic uncertainty regarding next period's abilities. The worker's problem is written as

$$
\begin{gathered}
V_{w}(a, \varepsilon, \theta)=\operatorname{Max}_{c, a^{\prime}}\left\{u(c)+\beta E \quad \operatorname{Max}\left(V_{e}\left(a^{\prime}, \varepsilon^{\prime}, \theta^{\prime}\right)-\Psi, V_{w}\left(a^{\prime}, \varepsilon^{\prime}, \theta^{\prime}\right), V_{r}\left(a^{\prime}, \varepsilon^{\prime}, \theta^{\prime}\right)\right)\right\} \\
a^{\prime}=w \varepsilon \bar{l}+(1+r) a-c \\
a \geq 0
\end{gathered}
$$

The term $\bar{l}$ is labor input which is inelastically provided by the worker. The parameter $\Psi$ denotes start-up costs that are paid in terms of utility if the worker decides to start his own business $^{12}$. We choose to capture start-up costs in utility terms as these costs involve administrative time-consuming procedures. ${ }^{13}$

Finally, the inactive worker's value function is given by

$$
\begin{aligned}
V_{r}(a, \mathcal{E}, \theta)=\operatorname{Max}_{c, a^{\prime}}\{u(c)+\beta E & \left.\operatorname{Max}\left(V_{e}\left(a^{\prime}, \mathcal{E}^{\prime}, \theta^{\prime}\right)-\Psi, V_{w}\left(a^{\prime}, \mathcal{\varepsilon}^{\prime}, \theta^{\prime}\right), V_{r}\left(a^{\prime}, \mathcal{E}^{\prime}, \theta^{\prime}\right)\right)\right\} \\
& a^{\prime}=\bar{p}+(1+r) a-c \\
& a \geq 0
\end{aligned}
$$

with $\bar{p}$ the average pension level or non employment benefit. Inactive people may decide to go back to the labor market. Notice that the inactive's value function $V_{r}\left(a^{\prime}, \varepsilon^{\prime}, \theta^{\prime}\right)$ is the same for the entrepreneur and the worker. We are aware that, in the countries of our sample, the pattern of inactivity benefits differ for workers and self-employed. However, in order to keep the model tractable, we calibrate the inactivity to similar values for the worker and the entrepreneur, which reduces the number of value functions and state variables in the model. This makes the economic mechanisms of the model more transparent and we leave this extension for future research.

The model cannot be solved analytically. Numerical methods based on value function iterations are implemented using a grid for asset holdings $a$. For a given interest rate and wage: (1) We solve the entrepreneur's profit maximization problem taking into account the occasionally binding borrowing constraint. We then get the demand for capital and the profit

\footnotetext{
${ }^{12}$ The introduction of start-up costs in heterogeneous agent model of occupation choice is mentioned in a footnote in Cagetti and De Nardi (2005) as a check for the robustness of their results. Luo (2005) argue that start - up costs are introduced in his model. However, they are calibrated to 0 . In both papers, the interplay between start-up costs, wealth and entry into entrepreneurship is not studied.

${ }^{13}$ As a robustness check, we have also developed a model with start-up costs in the budget constraint. The main results are not modified.
} 
function, (2) We solve worker's and entrepreneur's maximization problem, yielding saving decisions and occupational choice, (3) We use decisions rules to compute the distribution of wealth and iterate until convergence of the distribution. In Appendix B, definition of equilibrium and calibration are reported.

\subsection{Occupational Choice as a Function of Wealth}

Occupational decisions are made by comparing the expected utility of working in the corporate sector versus going into entrepreneurship. Expected indirect utilities are captured by value functions displayed in Figure 2. We first present the occupational choice without the inactivity option to illustrate how start-up costs affect the choice to become entrepreneur. The individual must choose between being worker or entrepreneur.

\section{Figure 2: Occupational Choice as a Function of Wealth (without retirement as an outside option, with start up costs)}

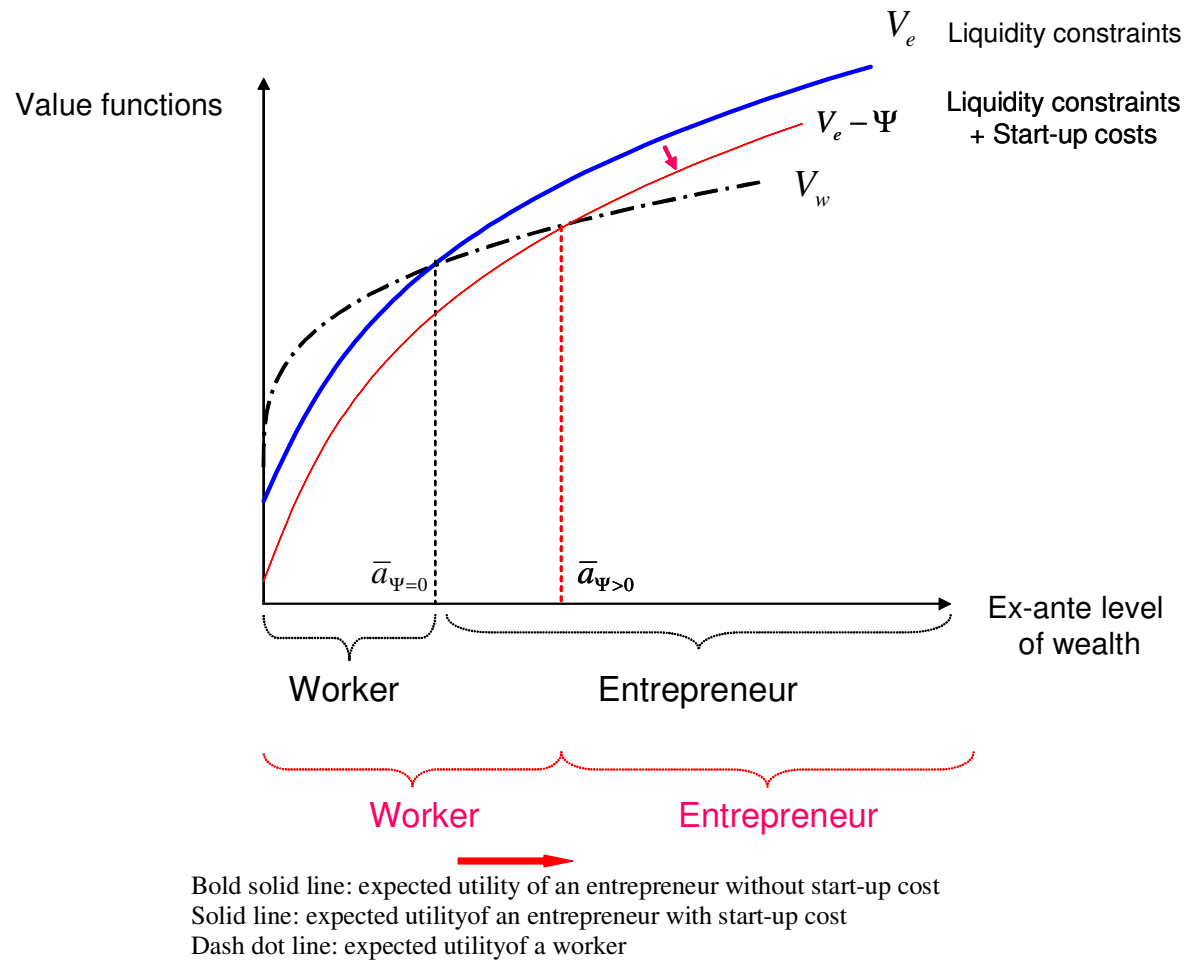

Let us first consider expected utilities for a worker $V_{w}$ and an entrepreneur $V_{e}$ in a liquidity constrained environment without start - up costs $(\Psi=0)$. Both curves intersect once, thereby defining a threshold level of wealth $\bar{a}_{\Psi=0}$. Individuals with low asset holdings $\left(a<\bar{a}_{\Psi=0}\right)$ prefer to be workers since they cannot borrow enough capital to start their own business. When they are wealthy enough to provide collateral to the bank, entrepreneurial activities become an attractive choice, all the more so as any increase in wealth allows entrepreneurs to borrow more and expand their own business.

With the introduction of start-up costs $(\Psi>0)$, the expected utility of entrepreneurship shifts downward thereby increasing the threshold wealth level beyond which the individual 
decides to run his own business. Working in the corporate sector is preferred to starting one's own business for a wider range of wealth. In a nutshell, higher start-up costs depress the marginal value of a dollar of additional wealth under liquidity constraints. This not only shifts down the fraction of entrepreneurs for all levels of wealth but also flattens the slope of the wealth profile.

Figure 2 actually captures the occupational choice of individual with highest entrepreneurial activities. However, two types of agents tend to discard the option to be self - employed (i.e. at all levels of wealth, $V_{w}>V_{e}$ : the value function of working in the corporate sector is higher than the one derived from entrepreneurial activities).

- First, agents with low abilities as entrepreneurs are all workers. Due to their lack of talent as entrepreneurs, they would rather remain workers whatever their level of wealth.

- In addition, individuals with high abilities as workers discard entrepreneurial activities since they can earn enough from the corporate sector and accumulate financial income from asset holding. They indeed enjoy the highest wages in the economy and are thus unwilling to give up the high outside opportunity to work in the corporate sector.

The value functions suggest that some self selection is at work in the model: untalented entrepreneurs as well as individuals with high ability as workers discard the option of starting their own business. As a result, the introduction of start-up will not modify their occupational choice.

Moreover, we get that low ability entrepreneurs and high ability workers are respectively located at the left and right hand sides of wealth distribution, while figure 2 illustrates occupational choice in the middle of wealth distribution. We develop this intuition assuming that low ability entrepreneurs are on the left hand side of wealth distribution while high ability workers are located at the other tail of wealth distribution. However, in our model, abilities are not perfectly correlated with wealth. ${ }^{14}$ With endogenous wealth and entry into entrepreneurship, there is no one-to-one relationship between the prevalence of selfemployment and wealth levels. The distribution of abilities across levels of wealth is actually given at the steady state by the endogenous equilibrium distribution.

When the individual has to choose between entrepreneur, worker and retiree, this choice is based on a comparison between 3 value functions (figure $3 \mathrm{a}$ ). When old age pension is not generous, the expected utility associated with retirement is very low. The occupational decision is then similar to the one presented in figure 2. In contrast, with generous pension schemes, the occupational choice is based on the intersection between 3 utility levels. The intersections between the 3 expected utility levels define 2 wealth thresholds. When the individual is poor, he chooses to work. If he is richer, he chooses to retire. The richest choose to become entrepreneurs.

\footnotetext{
${ }^{14}$ In contrast, Paulson, Townsend and Karaivanov (2006) assume that talent is a function of wealth and education. In our framework, abilities follow exogenous Markov processes that are ex ante independent of wealth levels.
} 


\section{Figure 3: Occupational Choice as a Function of Wealth (with retirement as an outside option)}

(a)

Low inactivity income

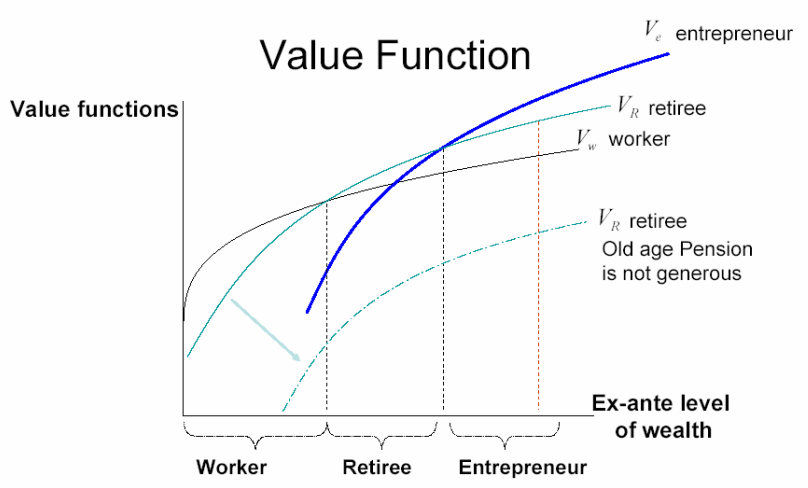

(b)

High inactivity income and start up costs

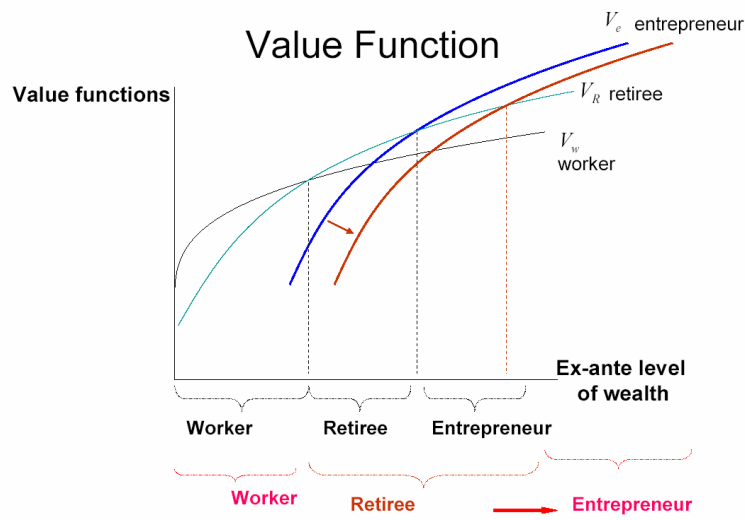

With start-up costs (figure 3b), the entrepreneur's expected utility shifts downward (as in figure 2), which increases the $2^{\text {nd }}$ wealth threshold beyond which entrepreneurial activities becomes a valuable option. With the increase in start-up costs, more individuals retire rather than start-up their own business.

The model therefore provides a characterization of individual's occupational choice. With panel data, we would have tested the predicted transition to entrepreneurship as a function of ex ante wealth (the individual's wealth level when the transition to selfemployment is observed). However, we have only one wave of SHARE data, which provides information of ex post wealth. In order to test the empirical predictions of the theoretical model, we must then identify the model's conclusions on occupational choices as a function of ex post wealth.

We calibrate the structural parameters of the model and compute the aggregate steady state equilibrium of the economy (see appendix B.2). After simulating choices made by all individuals in our economy, the aggregate equilibrium allows to characterize the relationship between the prevalence of entrepreneurship and ex post wealth. Figure 4 displays the fraction of entrepreneurs for each level of ex post wealth given by the endogenous steady state wealth distribution. Again, while figures 2-4 illustrate the mechanisms behind occupational choices as a function of ex-ante wealth, figure 4 reports a measure of the prevalence of self employment for each level of ex-post wealth. 


\section{Figure 4 Simulation of Fraction of Entrepreneurs as a Function of Ex Post Wealth}

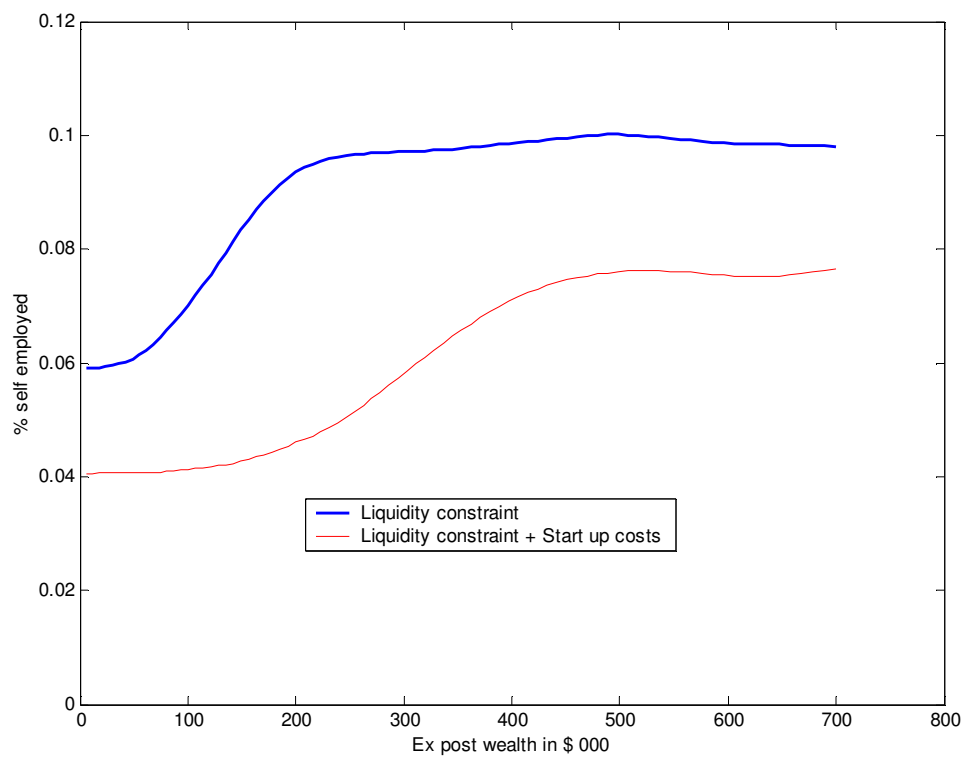

With limited liability, our model is consistent with Cagetti and De Nardi (2005)'s findings: the proportion of self employment increases with wealth. The model matches the current US fraction of self employed business owners $(8.9 \%$ in the model versus $7.6 \%$ in the data, reported in Cagetti and De Nardi (2005)). In absence of financial market imperfections, with one entrepreneurial ability level, the curve would have been totally flat. Limited liability indeed makes the model consistent with the view that higher wealth helps relax borrowing constraints and allows an expansion of private businesses.

The introduction of start-up costs shifts the curve downward as the economy is characterized by a lower aggregate proportion of self-employment ${ }^{15}$. Notice that the curve flattens in the middle of the distribution while the slope of the curve is left unchanged at the tails of wealth distribution: in the middle of the distribution, the introduction of start-up costs widens the range of wealth for which working in the corporate sector is preferable to entrepreneurial business. In addition, since the threshold occurs at higher wealth and value functions are concave in wealth, the marginal value of a dollar to a future entrepreneur decreases with higher start-up costs. In contrast, low ability individuals as entrepreneurs at the bottom of the distribution and wealthy high ability workers always discard the option of going into the non corporate sector, whatever the start-up costs.

\section{The estimation approach}

The average level of entrepreneurship results from theoretical predictions can be testable using cross-sectional data. Our empirical strategy is to look for a different relationship between the fraction of entrepreneurs and wealth in countries that have different potential for liquidity constraints and start-up costs. The prediction from the theoretical model

\footnotetext{
${ }^{15}$ Start up costs increase from 0 to 0.5 . The proportion of self employment in the steady state economy is then divided by 2 .
} 
is that the fraction of entrepreneur increases with wealth with liquidity constraints but that this relationship is attenuated with the presence of start-up costs (high start-up costs). Also, simulations from the model show that predictions held when looking at the stationary distribution of wealth in entrepreneurship and in paid work and they take into account the outside option of non working. Hence, we perform our analysis on the stock of entrepreneurs and workers and non working population in a given year and look at differences in the wealth distributions among the three groups.

An important assumption we make is that all other parameters of the model are constant (rate of interest, preferences, and transition matrices). At first sight, this might appear restrictive. Our empirical strategy will partially address this concern by controlling for various demographic characteristics as well as proxies for outside options (age fixed effect for retirement incentives).

\subsection{Empirical Strategy}

We use a multinomial choice model of entrepreneurship, work for pay and inactivity to test our predictions while controlling for observed individual characteristics (e.g. age, sex, education, marital status, household size, health status). An individual can choose to work as a worker, as an entrepreneur or to be inactive. We use quintile dummies for net wealth although we have experimented with a variety of other functional forms with the same results. When wealth is interacted with institutional indices, the theory tells us that

1) with more liquidity constraints the effect of wealth should be stronger

2) with more start-up costs, the effect of wealth should be lower

Hence, the proper test is one where we look at the sign of the parameters on the interactions between the wealth quintile dummies and the regulatory indices in the equation for entrepreneurship.

For each alternative $m=0,1,2(0=$ non working, $1=$ worker, $2=$ entrepreneur $)$, the value or utility flow is given by

$$
d_{i j, m}^{*}=x_{i j} \beta_{m}+\sum_{k=2} \gamma_{k, m} q_{i j, k}+\sum_{k=2} \delta_{k, m} q_{i j, k} \times r_{j}+\alpha_{j, m}+\varepsilon_{i j, m}
$$

We observe this choice if the value of the alternative $m$ is larger or

$$
d_{i j}=m \text { if } d_{i j, m}^{*}>d_{i j, m^{\prime}}^{*} \forall m^{\prime} \neq m
$$

where

- $d_{i j}$ denotes whether respondent $i$ in country $j$ is entrepreneur, worker or non worker.

- $x_{i j}$ denotes individual characteristics of respondent $i$ in the country $j$ : age, age squared, education, health, family type and size, sex ,...

- $\quad q_{i j, k}$ takes value 1 if the individual $i$ 's net wealth in country $j$ is in the $k$ th quintile (of the distribution across countries). We use quintiles of wealth in order to avoid any other particular non linear form (i.e. a polynomial form).

- $\quad r_{j}$ denotes the liquidity constraint index (LC) and they interact with the quintile of the individual's net wealth (we will also add to the estimation $s_{j}$, which the start-up cost index (SC) $\left.\sum_{k=2} \partial_{k} q_{i j, k} \times s_{j}\right)$ )

- While $\alpha_{j}$ denotes country fixed effects capturing other differences across countries ( $\alpha_{j}$ takes value 1 if the individual $i$ is in the country $j, 0$ otherwise). 
- To take into account the outside options (in financial terms) associated to be retiree, disable or unemployed, we include a quadratic in age as well as a dummy for the normal retirement age. Parameters of the quadratic in age are allowed to vary by country.

- The unobserved differences of individual characteristics are captured by $\varepsilon_{i j}$, which follows an extreme value distribution. This hypotheses allows us to write the probability of the alternatives $m$, as indicate as follows

$$
\begin{gathered}
v_{i j, m}=x_{i j} \beta_{m}+\sum_{k=2} \gamma_{k, m} q_{i j, k}+\sum_{k=2} \delta_{k, m} q_{i j, k} \times r_{j}+\alpha_{j, m}, \text { as given } \\
P\left(d_{i j}=m \mid v_{i j, 1}, \ldots, v_{i j, M}\right)=\frac{\exp \left(v_{i j, m}\right)}{\sum_{m^{\prime}} \exp \left(v_{i j, m^{\prime}}\right)}
\end{gathered}
$$

Our aim is to measure the effect of the liquidity constraints (LC) and the start-up costs (SC). To do so, we add these institutional elements as control variables with an interaction with wealth. The interaction can be interpreted as a weakening (or strengthening) of the relationship between the probability of being entrepreneur and the level of wealth as LC or SC change. We use inactivity as the comparison alternative. The parameters show the desire of choosing one or other option (worker/entrepreneur) respect to the comparison alternative (inactivity). Our hypothesis is that parameters $\delta$ are positive if wealth is interacted with LC and negative if interacted with SC. For example, to test if the relationship between the probability of being entrepreneur and the wealth is attenuated in countries with large start up costs, it must be verified that $\delta_{k, 2}<\delta_{k, 1}<0, \forall \mathrm{k}$. This test can be done as a joint test with the interaction parameters. The same test applies for interactions with liquidity constraints.

\subsection{Empirical Results}

We first estimate the multinomial model when wealth is interacted only with the liquidity constraint index (A complete presentation of results is shown in Appendix C). Startup costs are not included in the model. The results do not show a strong positive relationship between wealth and the probability of being entrepreneur in countries with more liquidity constraints (table 5). Although positive in the $5^{\text {th }}$ quintile, the interactions remain largely statistically insignificant. However, as shown on figure 1, countries with more liquidity constraints are also characterized with high start-up costs. From the theoretical prediction of the model, we know that higher start-up costs push the value function of being an entrepreneur outward hence increasing the wealth threshold above which one wishes to be entrepreneur. Since the value function is concave, this shift decreases the marginal incentive of one dollar of wealth. In other words, the relationship between the wealth and the probability of being entrepreneur is attenuated with higher start-up costs. Therefore, the omission of the start up cost can hide the positive relationship that exits between the liquidity constraints and the relation wealth-entrepreneurship. 


\section{Table 5 Multinomial Logit Analysis: Choice between Non Working, Working and}

Entrepreneur in Function of their Wealth and Liquidity constraints

\begin{tabular}{|c|c|c|c|}
\hline \multirow[b]{2}{*}{ Interaction with liquidity constraint index } & \multicolumn{2}{|c|}{ Comparison: inactivity } & \multirow[b]{2}{*}{ test difference } \\
\hline & workers & entrepreneur & \\
\hline \multirow[t]{2}{*}{ Q2 wealth X LC } & -0.108 & -0.257 & \\
\hline & -1.63 & -2.14 & \\
\hline \multirow[t]{2}{*}{ Q3 wealth X LC } & -0.055 & -0.108 & Chi2(4) $=5.75$ \\
\hline & -0.84 & -0.93 & $\mathrm{p}-\mathrm{val}=0.2185$ \\
\hline \multirow[t]{2}{*}{ Q4 wealth X LC } & 0.012 & -0.174 & \\
\hline & 0.19 & -1.53 & \\
\hline \multirow[t]{2}{*}{ Q5 wealth X LC } & 0.197 & 0.138 & \\
\hline & 2.7 & 1.20 & \\
\hline Fixed effects country/age & yes & yes & \\
\hline Individual features & yes & yes & \\
\hline $\mathrm{N}$ & 26949 & & \\
\hline Pseudo R2 & 0.240 & & \\
\hline
\end{tabular}

In table 6, we include interactions with SC and LC jointly. The results confirm the theoretical predictions. The relationship between wealth and entrepreneurship appears to be steeper with higher liquidity constraints. Coefficients are positive and statistically significant. With the interaction with the liquidity constraint index, the result becomes positive and significant at the $1 \%$ level in the $3^{\text {rd }}$ quintile, in the $4^{\text {th }}$ quintile and in the $5^{\text {th }}$ quintile. We have also experimented with limited heterogeneity in the effects of observed characteristics across countries with practically the same results.

On other hand, when we include start-up costs, the wealth gradient is attenuated by higher start-up costs, particularly in the $4^{\text {th }}$ and $5^{\text {th }}$ quintile of the wealth distribution where it is statistically significant at the $1 \%$ level. That means that inclusions of start-up cost are important to understand the relationship of being entrepreneur and wealth. Empirical results are consistent with our theoretical predictions: high start-up costs flatten the relationship between the prevalence of entrepreneurship and individual wealth by depressing the marginal value of being an entrepreneur as a function of initial wealth. The interaction with SC is negative in the middle of the wealth distribution for workers and entrepreneurs. However, it is more pronounced for entrepreneurs than for workers. This difference is statistically significant. 
Table 6 Multinomial Logit Analysis: Choice between Non Working, Working and Entrepreneur in Function of their Wealth, Administrative and Liquidity Constraints

\begin{tabular}{|c|c|c|c|}
\hline \multirow[b]{2}{*}{ Interaction with liquidity constraint index } & \multicolumn{2}{|c|}{ Comparison: inactivity } & \multirow[b]{2}{*}{ test difference } \\
\hline & workers & entrepreneur & \\
\hline \multirow[t]{2}{*}{ Q2 wealth X LC } & 0.222 & 0.255 & \\
\hline & 2.42 & 1.25 & \\
\hline \multirow[t]{2}{*}{ Q3 wealth X LC } & 0.253 & 0.596 & Chi2(4) $=9.98$ \\
\hline & 2.7 & 2.98 & $\mathrm{p}-\mathrm{val}=0.0408$ \\
\hline \multirow[t]{2}{*}{ Q4 wealth X LC } & 0.348 & 0.566 & \\
\hline & 3.62 & 2.85 & \\
\hline \multirow[t]{2}{*}{ Q5 wealth X LC } & 0.444 & 0.780 & \\
\hline & 4.03 & 3.79 & \\
\hline \multicolumn{4}{|l|}{ Interaction with startup costs index } \\
\hline \multirow[t]{2}{*}{ Q2 wealth X SC } & -0.574 & -0.610 & \\
\hline & -5.1 & -2.91 & \\
\hline \multirow[t]{2}{*}{ Q3 wealth X SC } & -0.484 & -0.916 & \\
\hline & -4.38 & -4.53 & \\
\hline \multirow[t]{2}{*}{ Q4 wealth X SC } & -0.522 & -0.961 & Chi2 $(4)=14.48$ \\
\hline & -4.67 & -4.78 & $\mathrm{p}-\mathrm{val}=0.0059$ \\
\hline \multirow[t]{2}{*}{ Q5 wealth X SC } & -0.390 & -0.825 & \\
\hline & -2.97 & -3.97 & \\
\hline Fixed effects country/age & yes & yes & \\
\hline Individual features & yes & yes & \\
\hline $\mathrm{N}$ & 26949 & & \\
\hline Pseudo R2 & 0.240 & & \\
\hline
\end{tabular}

We have tried other control variables and robustness that other studies use without any significant changes in the results. ${ }^{16}$ We have also taken into account the outside options (in financial terms) associated with being retiree, disable or unemployed, including flexible age patterns, where parameters were allowed to vary by country. We have also taken into account a dummy for the normal retirement age. Gruber and Wise (1999) indeed point out the importance of these incentives in the retirement decision. ${ }^{17}$

\section{Summary and Further Comments}

In this paper, we have developed a simple occupational choice model of entrepreneurship with liquidity constraints and start-up costs that yields testable predictions on the cross-section distribution of entrepreneurs in the wealth distribution. Our main prediction was that although liquidity constraints yield an increasing wealth profile of entrepreneurs, start-up costs depress this profile. Intuitively, this is due to the fact that with start-up costs, the threshold of wealth necessary to transit to entrepreneurship increases to a flatter portion of the value of being en entrepreneur. Hence, the marginal value of an additional dollar of wealth for entrepreneurship decreases with start-up costs, yielding a flatter wealth profile. Parametric evidence using comparable micro-data from 9 countries support this prediction. In countries where start-up costs are higher, the wealth profile of

\footnotetext{
16 i.e. different education definitions, individual health insurance situation, more disaggregated health measures and job characteristics. We have also tried our institutional measures, LC and SC, in interaction with wealth one by one.

${ }^{17}$ These interactions between age dummies and country variables only partially capture the different retirement incentives. However, retirement incentives also depend on past contributions, and not only on age. . For want of information on work history, past contributions are not included in our analysis.
} 
entrepreneurs is flatter while it is steeper in countries where more financial barriers are present.

However, one important omission from our analysis is that of size of business across countries. This too is affected by institutions. Indeed, the distribution of business asset distribution for entrepreneurs is very different across countries. Countries with both low SC and LC as the UK and US have a more diffuse distribution of "project size" compared to countries with both high SC and LC. A joint analysis of both the extensive margin (the decision to be entrepreneur) as well as the intensive margin (the size of business assets) is likely to provide a more complete picture of the effect of institutions on the prevalence of entrepreneurship. Furthermore, with the release of a second wave of data from SHARE, we can assess the robustness of these findings by looking at entry in each occupation as a function of initial wealth. 


\section{References}

Acs Z.J., P.Arenius, M.Hay and M. Minniti (2006) Global Entrepreneurship Monitor, Executive Report, London Business School, Babson, 2004.to Update

Blanchflower D. G. and A. Oswald, (1998) "What makes an entrepreneur? " Journal of Labor Economics, January, 16(1) pp. 26-60, 1998.

Blanchflower D. G. (2000) "Self-Employment in OECD Countries", Labour Economics, 7, September 2000, pp. 471-505.

Blondal, S. and S. Scarpetta (1999) "The Retirement Decision in OECD Countries", OECD Department Working Papers, n. 202.

Cagetti, M. and M. De Nardi, (2005): "Entrepreneurship, frictions, and wealth," Staff Report 322, Federal Reserve Bank of Minneapolis.

Evans D. and B. Jovanovic (1989), "An Estimated Model of Entrepreneurial Choice Under Liquidity Constraints". Journal of Political Economy, vol. 97, n²4, pp. 808-27.

Evans S. and L. Leighton (1989) "Some empirical aspects of entrepreneurship", American. Economic Review, 79(3), 519-535.

Fonseca R., P. Lopez-Garcia and C.A. Pissarides (2001). "Entrepreneurship, Start-up Costs and Employment", European Economic Review, 45, 692-705.

Gentry, W. and Hubbard R. G. (2000), "Entrepreneurship and Household Savings", American Economic Review, 90(2), 283-287.

GEM (2004), Global Entrepreneurship Monitor Global 2004 Executive Report, www.gemconsortium.org.

Guiso, L., P. Sapienza and L. Zingales (2002): "Does Local Financial Development Matter?," NBER Working Papers 8923, National Bureau of Economic Research, Inc

Gruber, J. et D.A Wise,. (eds.) (1999), "Social Security and Retirement Around the World" in The University of Chicago Press for the N.B.E.R., 1999

Harada, N. (2004), "Productivity and Entrepreneurial Characteristics in New Japanese", Firms, Small Business Economics, 23, 299-310.

Hochguertel, S. (2005): "Self-Employment around Retirement in Europe", presented at the SHARE-ELSA,HRS user conference in Lund. Economy, April 2004, Vol. 112(2), pp. 319-347.

Holtz-Eakin, D., D. Joulfaian, and H. S. Rosen (1994), "Entrepreneurial Decisions and Liquidity Constraints", The RAND Journal of Economics, 25, 334.347.

Hurst, E. and A. Lusardi (2004), "Liquidity Constraints, Household Wealth and Business Ownership," Journal of Political Economy, 112, 319-347.

Kapteyn, A. and C. Panis. (2003), "The Size and Composition of Wealth Holdings in the United States, Italy, and the Netherlands." NBER Working Paper Series, 10182. Cambridge, MA. December.

La Porta, R., F. Lopez-de-Silanes, A. Shleifer, and R.W. Vishny, (1998) "Law and Finance," Journal of Political Economy, 106(6), 1113-55.

Luo, Y. (2005): "Uninsurable Entrepreneurial risks, capital market Imperfections, and Heterogeneity in macroeconomy" Princeton University, Working Papers.

Nicoletti, G., S. Scarpetta and O. Boylaud (1999), "Summary Indicators of Product Market Regulation with an Extension to Employment Protection Legislation" OECD Economics Departement, Working Papers, 226.

Paulson A. L., Townsend, R.M. and Karaivanov A. (2006): "Distinguishing Limited Liability from Moral Hazard in a Model of Entrepreneurship." Journal of Political Economy 114(1): 100-144. 
Quadrini, V. (2000). "Entrepreneurship, Saving and Social Mobility,"” Review of Economic Dynamics 3(1): 1-40.

Reynolds P., N. Bosma, E. Autio, S. Hunt, N. De Bono, I. Servais, P. Lopez-Garcia and N. Chin (2005) "Global Entrepreneurship Monitor: Data Collection Design and Implementation 1998-2003" Small Business Economics (2005) 24: 205-231

Zissimopoulos, J. and L, Karoly (2007). "Transitions to Self-Employment at Older Ages: The Role of Wealth, Health, Health Insurance and Other Factors" in in Labour Economics: 14(2) 269-295. 


\section{Appendix A Definitions of Variables}

\section{Table A1 Definition variables}

\begin{tabular}{ll}
\hline \hline Variables & Definitions \\
& and HRS. \\
Dependent variable & selt-employment is a selt-reported variable, working are wage pard and non \\
& working are retirees, unemployed, disabled and others. \\
& Multilogit analysis we have used non working in the base outcome versus \\
& self-employed and working. It is our benkmark \\
rself_stat & \\
Independent variables &
\end{tabular}

Demographic variables

Age

with more than 50 years old and less of 80 years old

Gender as control variable is considered, (male dummy)

Marital Status

Marital Status as control variable is considered, (married dummy)

We consider two education levels, following the ISCE-1997 for SHARE and For ELSA High skilled is nvq4/nvq5/degree or equiv Middle skilled higher ed below degree, nvq3/gce a level equiv and nvq2/gce o level equiv and low skilled are nvq1/cse other grade equiv, foreign/other and no qualification. In the case of HRS we consider High skilled are some college and college and above, middle skilled is high-school graduate and low skilled are lt high-school and ged. We study low and middle skilled together

Education versus high educated.

Household size Household size is also considered as control variable

Health variables Three levels of health self-reported to complete. Very good health, good Health and fair/poor health. The omitted variable is very good health.

Main variables

Quantiles of net wealth wealth analysis and comparison across data base reported as in table A.1 net wealth to institutional variables

Omitted variable the first quantile.

Institutional variables Start up index and Liquidity constraint index. More information in Section country dummies age dummies Interactions between country dummies and age dummies as well as normal retirement age dummy are considered. 
Table A2 Classification of Assets

\begin{tabular}{|c|c|c|c|}
\hline \multicolumn{2}{|l|}{ Assets } & \multicolumn{2}{|c|}{ Liabilities } \\
\hline $\begin{array}{l}\text { Risky Assets (stocks, bonds) } \\
\text { Safe Assets (cash, savings account) } \\
\text { Gross housing (equity + mortage) } \\
\text { other (transportation, other real assets) } \\
\text { business assets }\end{array}$ & $\begin{array}{l}\text { ha_r } \\
\text { ha_s } \\
\text { ha_h } \\
\text { ha_o } \\
\text { ha_b }\end{array}$ & $\begin{array}{l}\text { Debt (mortage+other) } \\
\text { Net Worth }\end{array}$ & $\begin{array}{l}\text { ha_d } \\
\text { ha_nw }\end{array}$ \\
\hline Gross wealth & ha_gw & Gross wealth & ha_gw \\
\hline
\end{tabular}

Notes: Adapted from Kapteyn and Panis (2003) 


\section{Appendix B : Solving the model}

\section{B.1. Definition of Equilibrium}

Our heterogeneous agent model is based on a steady state economy without aggregate uncertainty. The stationary equilibrium consists of agents' choices for consumption, savings and occupational choice $\{c(a, \mathcal{\varepsilon}, \theta), a(a, \mathcal{\varepsilon}, \theta), \Gamma(a, \mathcal{\varepsilon}, \theta)\}$, value functions $\left\{V_{w}(a, \mathcal{\varepsilon}, \theta), V_{w}(a, \mathcal{\varepsilon}, \theta)\right\}$, a stationary distribution of households $\lambda(a, \varepsilon, \theta)$ and a set of aggregate variables $\{A, L, K\}$ such that

i. Entrepreneurs maximize their profits, thereby choosing an investment size $k(a, \varepsilon, \theta)$.

ii. Saving decisions for workers $a^{\prime}=g_{w}(a, \varepsilon, \theta)$ and entrepreneurs $a^{\prime}=g_{e}(a, \mathcal{\varepsilon}, \theta)$ as well as occupational choice $\gamma=\Gamma(a, \varepsilon, \theta)$ are solutions to workers and entrepreneurs' maximization problems where

$$
\Gamma(a, \mathcal{\varepsilon}, \theta)=\left\{\begin{array}{cc}
1 & \text { if } E\left[V_{e}(a, \mathcal{\varepsilon}, \theta)\right]>E\left[V_{w}(a, \mathcal{E}, \theta)\right] \\
0 & \text { otherwise }
\end{array}\right.
$$

for all ability levels $(\varepsilon, \theta)$. The household's policy function $a^{\prime} \equiv \Omega(a, \varepsilon, \theta)$ eventually depends on occupational decision such that

$$
\Omega(a, \mathcal{\varepsilon}, \theta)=\Gamma(a, \mathcal{\varepsilon}, \theta) g_{e}(a, \mathcal{\varepsilon}, \theta)+[1-\Gamma(a, \varepsilon, \theta)] g_{w}(a, \varepsilon, \theta)
$$

iii. The endogenous invariant distribution $\lambda(a, \varepsilon, \theta)$ consistent with optimal household's decisions $\Omega(a, \mathcal{E}, \theta)$ is such that

$$
\lambda\left(a^{\prime}, \varepsilon^{\prime}, \theta^{\prime}\right)=\sum_{s} \sum_{\left\{a: a^{\prime}=\Omega(a, \varepsilon, \theta)\right\}} \lambda(a, \varepsilon, \theta) \pi\left(\varepsilon^{\prime}, \theta^{\prime} / \varepsilon, \theta\right)
$$

where $\pi\left(\varepsilon^{\prime}, \theta^{\prime} / \varepsilon, \theta\right)$ denotes the Markov processes governing changes in ability levels.

iv. The real interest rate and wage are such that capital and labor markets clear. The equilibrium aggregate capital supply and demand are denoted $A$ and $K$ respectively. Supply of capital given by optimal saving choices equals the demand for capital from the entrepreneurial and corporate sectors:

$$
\sum_{\varepsilon, \theta} \sum_{a} \lambda(a, \mathcal{\varepsilon}, \theta) k(a, \mathcal{\varepsilon}, \theta)+K_{c}=\sum_{\varepsilon, \theta} \sum_{a} \lambda(a, \mathcal{\varepsilon}, \theta) g(a, \mathcal{\varepsilon}, \theta)
$$

Labor demand stems from the corporate sector and equals the labor supplied by workers. The equilibrium aggregate labor is denoted $L$.

$$
L_{c}=\sum_{\varepsilon} \sum_{a} \lambda(a, \varepsilon, \theta) \bar{l} \varepsilon
$$

v. The wage and interest rate are given by the marginal productivity of each factor of production.

\section{B. 2. Calibration}

We calibrate the economy on US data as a benchmark in order to stress the specific impact of key parameters of our model: start-up costs $(\Psi)$ and the tightness of borrowing constraints $(\kappa)$. In the benchmark calibration, start-up costs are set to 0 before increasing to 0.5. $\kappa$ is calibrated to a middle value of 0.6. Other parameter values are based on Cagetti and De Nardi (2005)'s and Luo (2005)'s. Utility is $\log : u(c)=\log (c)$. Table 3 summarizes the calibration. 
Table B.2.1 Calibration of Parameters

\begin{tabular}{lll} 
Parameter & Definition & Value \\
\hline \hline Technology : & & \\
\hline $\boldsymbol{\delta}$ & Depreciation rate & 0.08 \\
$\alpha$ & Share of capital in the corporate sector & 0.36 \\
& & \\
$\boldsymbol{V}$ & Return to scale in entrepreneurial sector & 0.88 \\
& & \\
Preferences: & & \\
\hline$\beta$ & Discount factor & 0.95 \\
$\bar{l}$ & Labor supply & $1 / 3$ \\
\hline \hline
\end{tabular}

Ability shocks follow exogenous and independent Markov processes estimated by Luo (2005) based on PSID data. Grid points for working abilities (normalized to an average of one) are $\varepsilon=[0.57 ; 0.93 ; 1.51]$. The transition matrix $\pi\left(\varepsilon^{\prime} / \varepsilon\right)$ is

$$
\left[\begin{array}{lll}
0.75 & 0.24 & 0.01 \\
0.19 & 0.62 & 0.19 \\
0.01 & 0.24 & 0.75
\end{array}\right]
$$

Entrepreneurial talents evolve according to a Markov matrix that is independent of working abilities. $\theta=[1 ; 1.26 ; 1.68]$ with

$$
\pi\left(\theta^{\prime} / \theta\right)=\left[\begin{array}{ccc}
0.9 & 0.1 & 0 \\
0.1 & 0.7 & 0.2 \\
0.265 & 0.265 & 0.47
\end{array}\right] .
$$

Considering 3 working abilities and 3 levels of entrepreneurial talents, we have 9 possible combinations of abilities $(\varepsilon, \theta)$. Finally, the steady state equilibrium interest rate in the economy without start-up costs equals $5 \%$, which is consistent with long run data in OECD countries. Inactivity income is set at $40 \%$ of average income in the economy, which is consistent with Cagetti and De Nardi (2005). 


\section{Appendix C Detail Results of Estimations}

Table C.2. Results with Liquidity Constraints Interactions

\begin{tabular}{|c|c|c|}
\hline \multirow[b]{2}{*}{ Interaction with liquidity constraint index } & \multicolumn{2}{|c|}{ comparison: inactivity } \\
\hline & worker & entrepreneur \\
\hline country Fixed & yes & yes \\
\hline age Fixed & yes & yes \\
\hline age $*$ country dummies & yes & yes \\
\hline \multirow[t]{2}{*}{ male } & 0.592 & 1.171 \\
\hline & 18.36 & 24.33 \\
\hline \multirow[t]{2}{*}{ married } & -0.201 & -0.311 \\
\hline & -4.5 & 0.01 \\
\hline \multirow[t]{2}{*}{ household size } & 0.039 & 0.320 \\
\hline & 2.13 & 0.36 \\
\hline \multirow[t]{2}{*}{ high educated } & 0.516 & 0.428 \\
\hline & 13 & 7.29 \\
\hline \multirow[t]{2}{*}{ health good } & -0.434 & -0.387 \\
\hline & -11.63 & -7.1 \\
\hline \multirow[t]{2}{*}{ health fair/poor } & -1.485 & -1.395 \\
\hline & -31.09 & -17.72 \\
\hline \multirow[t]{2}{*}{ Q2 wealth } & 0.499 & 0.646 \\
\hline & 6.69 & 5.1 \\
\hline \multirow[t]{2}{*}{ Q3 wealth } & 0.554 & 0.845 \\
\hline & 7.6 & 6.97 \\
\hline \multirow[t]{2}{*}{ Q4 wealth } & 0.472 & 1.079 \\
\hline & 6.42 & 8.94 \\
\hline \multirow[t]{2}{*}{ Q5 wealth } & 0.268 & 1.480 \\
\hline & 3.21 & 11.87 \\
\hline \multirow[t]{2}{*}{ Q2 wealth X LC } & -0.108 & -0.257 \\
\hline & -1.63 & -2.14 \\
\hline \multirow[t]{2}{*}{ Q3 wealth X LC } & -0.055 & -0.108 \\
\hline & -0.84 & -0.93 \\
\hline \multirow[t]{2}{*}{ Q4 wealth X LC } & 0.012 & -0.174 \\
\hline & 0.19 & -1.53 \\
\hline \multirow[t]{2}{*}{ Q5 wealth X LC } & 0.197 & 0.138 \\
\hline & 2.7 & 1.20 \\
\hline \multirow[t]{2}{*}{ constant } & 0.895 & -1.800 \\
\hline & 2.76 & -3.22 \\
\hline $\mathrm{N}$ & 26949 & \\
\hline Pseudo R2 & 0.240 & \\
\hline
\end{tabular}


Table C.3. Results with Liquidity Constraints and Start up Costs Interactions

\begin{tabular}{|c|c|c|}
\hline \multirow[b]{2}{*}{ Interaction with LC and SC index } & \multicolumn{2}{|c|}{ comparison: inactivity } \\
\hline & worker & entrepreneur \\
\hline Country Fixed & yes & yes \\
\hline age Fixed & yes & yes \\
\hline age*country dummies & yes & yes \\
\hline \multirow[t]{2}{*}{ male } & 0.594 & 1.174 \\
\hline & 18.39 & 24.37 \\
\hline \multirow[t]{2}{*}{ married } & -0.208 & -0.325 \\
\hline & -4.64 & -4.76 \\
\hline \multirow[t]{2}{*}{ household size } & 0.039 & 0.010 \\
\hline & 2.17 & 0.35 \\
\hline \multirow[t]{2}{*}{ high educated } & 0.516 & 0.426 \\
\hline & 12.97 & 7.25 \\
\hline \multirow[t]{2}{*}{ health good } & -0.430 & -0.379 \\
\hline & -11.51 & -6.96 \\
\hline \multirow[t]{2}{*}{ health fair/poor } & -1.482 & -1.391 \\
\hline & -30.97 & -17.62 \\
\hline \multirow[t]{2}{*}{ Q2 wealth } & 0.455 & 0.796 \\
\hline & 6.1 & 5.92 \\
\hline \multirow[t]{2}{*}{ Q3 wealth } & 0.556 & 0.974 \\
\hline & 7.8 & 7.51 \\
\hline \multirow[t]{2}{*}{ Q4 wealth } & 0.479 & 1.221 \\
\hline & 6.68 & 9.47 \\
\hline \multirow[t]{2}{*}{ Q5 wealth } & 0.274 & 1.615 \\
\hline & 3.36 & 12.18 \\
\hline \multirow[t]{2}{*}{ Q2 wealth X LC } & 0.222 & 0.255 \\
\hline & 2.42 & 1.25 \\
\hline \multirow[t]{2}{*}{ Q3 wealth X LC } & 0.253 & 0.596 \\
\hline & 2.7 & 2.98 \\
\hline \multirow[t]{2}{*}{ Q4 wealth X LC } & 0.348 & 0.566 \\
\hline & 3.62 & 2.85 \\
\hline \multirow[t]{2}{*}{ Q5 wealth X LC } & 0.444 & 0.780 \\
\hline & 4.03 & 3.79 \\
\hline \multirow[t]{2}{*}{ Q2 wealth X SC } & -0.574 & -0.610 \\
\hline & -5.1 & -2.91 \\
\hline \multirow[t]{2}{*}{ Q3 wealth X SC } & -0.484 & -0.916 \\
\hline & -4.38 & -4.53 \\
\hline \multirow[t]{2}{*}{ Q4 wealth X SC } & -0.522 & -0.961 \\
\hline & -4.67 & -4.78 \\
\hline \multirow[t]{2}{*}{ Q5 wealth X SC } & -0.390 & -0.825 \\
\hline & -2.97 & -3.97 \\
\hline \multirow[t]{2}{*}{ constant } & 0.869 & -1.803 \\
\hline & 2.68 & -3.23 \\
\hline $\mathrm{N}$ & 26949 & \\
\hline Pseudo R2 & 0.240 & \\
\hline
\end{tabular}

